\title{
ФИКСИРУЕМ ТЕНДЕНЦИЮ
}

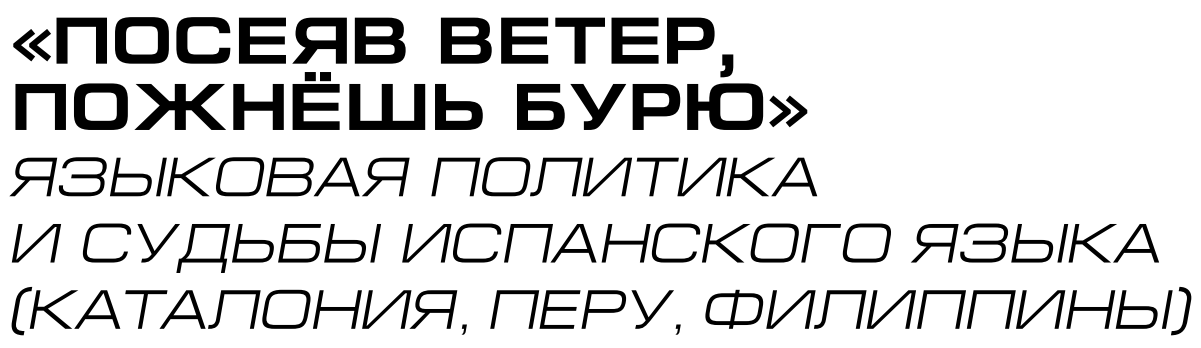

ЕЛЕНА ГРИНИНА

ГАЛИНА РОМАНОВА

МГИМО МИД России, Москва, Россия

\section{Резюме}

Отличительной чертой современной эпохи является то, что чем активнее идет процесс глобализации, тем выше интерес различных этнических групп к своим родным языкам, которые рассматриваются ими как по существу единственное оставшееся у них средство самоидентификации. Сегодня и политологи, и лингвисты изучают язык как важнейшую часть социальной реальности, а языковая политика стала мощным инструментом политики государственной.

Статья посвящена анализу современной языковой политики через призму языковых ситуаций, сложившихся в трёх разных странах и автономных регионах: Каталонии, Перу и Филиппинах. Их объединяет то, что испанский язык, будучи экзогенным для этих территорий, насаждался в XVI веке по сути одинаковыми методами. Однако его судьба сложилась по-разному в каждом из рассматриваемых примеров. Например, в Каталонии и Перу ему удалось вытеснить автохтонные языки практически из всех сфер социальной жизни общества, кроме бытового общения. Но с течением времени автохтонные языки стали постепенно восстанавливать свои функции, причём процесс нормализации каталанского языка пошёл настолько успешно, что испанское правительство обеспокоилось положением испанского языка на территории Каталонии. В Перу язык кечуа (runasimi) получил статус коофициального языка, нормализационные и кодификационные процессы ещё только запускаются, при этом происходит тесное взаимодействие и взаимовлияние эндогенного и экзогенного языков как факторов формирования национальной идентичности. Иная ситуация сложилась на Филиппинах, где испанский язык, благодаря последовательной языковой политике, стал прочно ассоциироваться с колониальным прошлым этой страны и к концу XX века вышел из употребления, а на его место пришёл английский язык. Рассмотренные примеры показывают зависимость успешности и характера протекания политических процессов от сбалансированности языковой политики, проводимой администрацией в полиэтничном обществе.

\section{Ключевье слова:}

языковая политика; языковая ситуация; мультилингвизм; билингвизм; диглоссия; языковое мировидение; языковая личность; испанский язык; каталанский язык; кечуа; английский язык; Каталония; Перу; Филиппины.

\footnotetext{
Дата поступления рукописи в редакцию: 13.12.2018

Дата принятия к публикации: 29.09.2019

Для связи с авторами / Corresponding author:

Email: eagrinina@yandex.ru
} 
Противоречия по языковым вопросам выступают одним из главных катализаторов кризисов, происходящих сегодня на мировой сцене. В этой связи отечественный специалист У.Б. Азизов утверждает: «В сфере международных отношений мы находимся в бесконечном процессе конструирования миров через наше восприятие, которое в свою очередь опосредовано языком... Разные цели стран конструируют разные миры через язык» [Азизов 2015: 60]. И.В. Чернов, исходя из того, что любой социум представляет собой коммуникативноязыковое сообщество, обосновывает принципы лингвополитического реализма, поскольку «язык как инструмент общения является важнейшей частью социальной реальности. Уже никто не спорит с тем, что изменение орудий труда и технологий неизбежно имеет социально-экономические последствия. Поэтому очевидно, что ... язык не может исключаться из изучения социально-политической реальности» [Чернов 2018: 87]. Другие исследователи связывают язык с проблемами этноса и национальной идентичности [Тишков 2008]. Социолингвисты подхватывают эту тему, делая упор на этноязыковые конфликты [Марусенко 2015б] и на языковые последствия глобализации [Марусенко 2015а].

Конфликтный потенциал языковых процессов обусловлен тем, что ускорение глобализации сопровождается растущим стремлением людей к использованию и сохранению родной речи, вызванным ощущением угрозы со стороны более сильных конкурентов ${ }^{1}$. Некоторые государства учитывают эти настроения, что способствует формированию языковой политики как самостоятельного аспекта национальных стратегий, как, например, в Перу [Espezúa 2017: 18-25].

Пути развития социально-языковых взаимоотношений в контексте политики правительства рассматриваются в данной статье на трёх контрастных примерах, в которых государственным языком на длительном отрезке времени является или являлся испанский: Испания (регион Каталонии), Перу и Филиппины. Их выбор не случаен, поскольку на все эти территории испанский язык пришёл примерно в одно и то же время - в эпоху подъёма Испанской империи. Он накладывался на языки местного населения, стремясь вытеснить их и установить собственную монополию. В настоящее время во всех трёх случаях происходит изменение языковой ситуации, причём оно носит разнонаправленный характер. В статье рассматриваются социально-политические причины такой дивергенции.

\section{1}

Термином «языковая политика» в социолингвистике обозначают сознательное воздействие общества на регулирование использования языка. Максимально полное определение, вслед за Ф. Грином, Р. Йенсдоттир и О. Риганом, ей даёт известный отечественный социолингвист М.А. Марусенко, считающий, что «систематические рациональные меры, основанные на теоретическом анализе, применяемые ко всему обществу и направленные на решение языковых проблем, содействуют повышению всеобщего благоденствия. Руководство языковой политикой осуществляют государственные власти или их уполномоченные; она касается всего населения, находящегося под их юрисдикцией, или какой-либо его части» [Марусенко 2014: 7-8].

Основным инструментом языковой политики выступает сам язык, поскольку именно он играет важную роль в моделировании картины мира населения, хранит и передаёт из поколения в поколение информацию в виде концептов, идеологем и мифологем. В истории много примеров неграмотной языковой политики, когда правительство той или иной страны, объявив о запрете на использование языков на-

\footnotetext{
1 Ярким примером может служить изменение отношения к окситанскому языку во Франции, который уже не рассматривается как непрестижный patois. Более того, знание окситанского позволяет лучше познать свои корни, культуру и самобытность своей родной земли [Martel 2013, 530].
} 
циональных групп или этнических меньшинств, проживающих на её территории, создавали очаги напряжённости.

Примером агрессивной языковой политики выступает навязывание со стороны более развитых государств менее развитым своего языка. Известный американский социолингвист Дж. Фишман отождествляет этот процесс с вестернизацией [Fishman 1974: 79-102]. Суть языковой экспансии англосаксонского мира сводится к повсеместному распространению английского языка и обязательности его изучения практически на всех уровнях образования. Аналогичную политику проводила Испания в отношении автохтонных языков.

Другой, практически противоположный, вариант решения языковых вопросов - мультикультурализм, который имеет два основных толкования. В широком смысле он нацелен на искоренение любой социальной или политической дискриминации по отношению к тем этническим группам, язык, культура или религия которых отличаются от принятых большинством населения страны. В узком смысле мультикультурализм трактуется не только как гарантия выживаемости отдельных этнических групп, но и как необходимость официального признания их прав, вплоть до возможности самоопределения [Abellán 2003: 18]. Такое понимание грозит вылиться в подрыв государственности и территориальной целостности страны.

В Испании имеют место два прямо противоположных случая. Аранская долина, входящая в состав Каталонии, получила право на самоопределение с принятием закона «Об особом статусе Арана» от 5 февраля 2015 года, в котором одна из статей гласит о том, что Парламент Каталонии признаёт право аранского народа определять своё будущее ${ }^{2}$. В то же время пра- вительство Испании отказывает в предоставлении такого права самой Каталонии, используя при этом не только юридические обоснования, но и силовые методы [Гринина 2016: 99-100; Прутцков 2018: 119-123].

На протяжении последних тридцати лет мультикультурализм являлся (и в декларативном плане остаётся до сих пор) идеологической базой политики Европейского Союза [Марусенко 2014]. В то же время потоки беженцев из стран Ближнего Востока и Северной Африки, эмигрантов из более близких регионов, перевернувшие размеренную жизнь европейцев, стали испытанием для жителей и правительств государств-членов ЕС. Они продемонстрировали, что население европейских стран не всегда готово следовать ранее провозглашенным принципам толерантности, равноправия, свободного перемещения, когда речь идёт о беженцах из третьих стран, которые не стремятся к языковой адаптации, не говоря о культурной интеграции ${ }^{3}$. Это свидетельствует об ограничениях проведения политики мультикультурализма в Европе [Куропятник, Куропятник 2018: 31-32].

Наиболее распространённые типы языковых ситуаций в мире - билингвизм и $\partial u$ глоссия. Эти термины восходят к латинским и греческим корням, обозначающим двуязычие. Вместе с тем под первым подразумевают использование в обществе двух языков, обладающих равными правами и имеющих полный набор функций, тогда как под диглоссией принято понимать «одновременное существование в обществе двух языков или двух форм одного языка, применяемых в разных функциональных сферах» [Виноградов 1990: 136].

\footnotetext{
${ }^{2}$ El Parlamento de Cataluña reconoce el derecho del pueblo aranés a decidir su futuro (primera disposición adicional] [LEY 1/2015, de 5 de febrero, del régimen especial de Arán].

3 Проблемы мультикультурализма в современной Европе ранее широко освещались в научных публикациях. 0 его ограничениях писали ещё до 2014 года. См., например: Гаман-Голутвина О.B. Проблема мультикультурализма в современной Европе // Вестник МГИМО (У). 2011. № 6 [21]. С. 16-18; Харитонов И.Н. (2012). Кризис политики мультикультурализма и ксенофобия в странах Европы // Социологический альманах, (3).
} 
Определение билингвизма затруднено нерешённостью вопроса о том, кто или что является объектом исследования: человек, коллектив, социальная группа, общество или целая территория. По мнению испанского социолингвиста Санчеса Карриона, который разделяет билингвизм на индивидуальный, социальный и территориальный, языковой конфликт может возникнуть только в рамках социального билингвизма, поскольку общество диктует, а иногда и навязывает правила и сферы использования того или иного языка [Sanchéz Carrión 1976: 60].

Данная проблематика стала особенно актуальной в связи с интенсивностью миграционных процессов. В связи с этим всё чаще речь идёт не о билингвизме, а о многоязычии (мультилингвизме). Известный российский специалист В.Г. Гак выделил следующие типы языковых ситуаций: сплошное индивидуальное многоязычие, множественное территориальное одноязычие, асимметричное двуязычие, «перевёрнутое» асимметричное двуязычие и «многоярусное» многоязычие [Гак 1989: 126-127]. Сплошное индивидуальное многоязычие характерно для Люксембурга, где родным для населения выступает один из немецких диалектов, но школа обеспечивает знание немецкого и французского литературных языков. Примером множественного территориального одноязычия выступает Швейцария, где в каждом из кантонов представлен свой официальный язык, являющийся родным для этого региона. Следует, однако, отметить, что в наши дни практически все швейцарцы многоязычны. Пример асимметричного двуязычия даёт Испания, поскольку часть населения одноязычна, а те автономные области, в которых региональный язык признан коофициальным, - двуязычны. В качестве примера «перевернутого» асимметричного двуязычия В.Г. Гак приводит Каталонию по отношению к испаноговорящим, которые, переселившись на территорию языкового меньшинства, не готовы адаптироваться в языковом отношении, что создаёт почву для конфликтов. При «многоярусном» мно- гоязычии, складывающемся на миноритарных территориях, где проживают группы третьего языка, местному населению приходится осваивать родной, официальный и государственный языки, как это происходит сегодня в Аранской долине [Гринина 2015: 337-338].

Таким образом, языковая ситуация зависит от экстралингвистических условий, которые складываются в данном обществе. Это означает, что диглоссия может со временем обернуться билингвизмом, как это произошло, например, в Испании (в Каталонии, Галисии и Стране Басков), а билингвизм стать диглоссией, как на юге Франции, где языковая политика французского правительства не позволяет носителям окситанского языка восстановить его изначальные функции [Гринина 2013: 73-75; Романова 2016: 90-91].

Даже в странах, уделяющих постоянное внимание вопросам би(мульти)лингвизма и диглоссии, включая самые экономически и социально благополучные, периодически возникают противоречия на почве языка в административной, образовательной, производственной и культурно-бытовой сферах [Educación 2018]. Ситуация би(мульти)лингвизма или диглоссии осложняется, если речь идёт о сосуществовании на одной территории в рамках единого государственно-административного целого не близких в культурно-историческом и языковом плане этнических сообществ (например, испанского и каталанского), а резко отличающихся друг от друга по всем параметрам субстратных (автохтонных) и суперстратных групп (Перу, Филиппины).

Выбор материала для данной статьи, а именно: анализ социолингвистических ситуаций, сложившихся в Каталонии, Перу и на Филиппинах, обусловлен тем, что при старте с примерно одинаковых позиций (насаждение испанского языка в XVI веке похожими методами) результаты оказались различными, и это объясняется прежде всего экстралингвистическими факторами, в частности сбалансированностью языковой политики или её недальновидностью. 
Испания, будучи страной полиэтнической и мультикультурной, даёт примеры широкого разнообразия языковых ситуаций на своей территории. Авторы рассматривают пример Каталонии, которая в последние годы привлекает к себе пристальное внимание стремлением отделиться от Мадрида и создать самостоятельное государство.

Языковую ситуацию в Каталонии до XII в. можно охарактеризовать как моноязычную. В период расцвета (XIII-XV века), помимо каталанского языка, на этих территориях появляется ещё один участник провансальский язык, который активно использовался в поэзии. Каталония и юг Франции в Средние века представляли собой единое культурное пространство, схожесть каталанского и провансальского языков способствовала взаимопониманию. Окситанский язык (современное название провансальского языка) в настоящее время остаётся наряду с испанским и каталанским официальным языком Аранской долины, входящей в состав Каталонии [Гринина 2016: 97]. Вместе с тем языковая ситуация на этой небольшой территории в данной статье специально не рассматривается.

Когда к началу XVI века, после вхождения в состав Испанской империи, Каталония утратила самостоятельность, ситуация стала постепенно меняться. Если мудрая политика Карлоса I (1516-1556) была нацелена на сохранение всех языков в королевстве как национального богатства, то его преемник Филипп II (1556-1598) резко сменил курс, отдавая приоритет испанскому и добиваясь сокращения функций автохтонных языков на всей территории своей обширной империи. С этого момента Каталония постепенно начала становиться двуязычной. Однако коренной перелом в пользу испанского языка произошёл в XVIII веке. В 1715 г. Филипп V (17001746) декретом «Planta Nueva» упразднил традиционные каталанские политические институты и лишил каталанский язык статуса официального. Отныне все документы издавались только на испанском языке, а с
Таблица 1

Параметры языковой ситуации в Каталонии, \%

\begin{tabular}{|l|l|}
\hline Понимают каталанский язык & 95,1 \\
\hline Говорят на каталанском языке & 73,1 \\
\hline Читают на каталанском языке & 78,7 \\
\hline Пишут на каталанском языке & 55,7 \\
\hline
\end{tabular}

Источник: Idescat https://www.idescat.cat/indicadors/ $? i d=$ anuals $\& n=10363$

1768 г. преподавание в школе велось полностью на нём [Vilar 2011]. Со временем на смену билингвизму пришла диглоссия, а приверженность населения монархии была замещена республиканскими настроениями, как никогда живыми среди каталонцев в наши дни.

Хотя начиная с XVIII века языковая экспансия со стороны испанского языка заметно усиливалась, на каталанском продолжали публиковаться манифесты в защиту родной речи, художественные произведения, учебники, грамматики и словари. Максимальному давлению со стороны испанского каталанский язык подвергался в период диктатуры Франко (1939-1975). В этот период региональному языку была оставлена только одна сфера использования - общение внутри семьи. Серьёзное изменение языковой политики Испании произошло с принятием Конституции 1978 года, когда страна вернулась на демократический путь развития. Ряд законодательных актов восстанавливал статус каталанского языка как официального и возвращал его в местную администрацию, систему образования, другие сферы каталанского общества [Pujol 2013]. Предпринятые меры по нормализации каталанского языка были настолько успешны, что сегодня уже не приходится говорить о диглоссии, а только о билингвизме (это подтверждается статистическими данными - табл. 1).

Участниками нынешней языковой ситуации в Каталонии выступают два языка: испанский как государственный и каталанский как официальный для данного автономного сообщества. Согласно результатам опроса, проведённого Департаментом культуры Правительства Каталонии и 
Институтом статистики (Idescat) в 2013 году, испанский выступал языком повседневного общения для $50,7 \%$ населения Каталонии, а каталанский - для $36,3 \%$, оба языка в равной мере использовали 6,8\% жителей ${ }^{4}$. Испанский язык предпочитают использовать при общении с государственной администрацией на федеральном уровне $(47,5 \%)$, в банках $(43,3 \%)$, в медицинских центрах $(46,3 \%)$, в магазинах $(48,7 \%)$. Выбор в пользу каталанского языка предпочтителен при общении с местными органами власти $(47,9 \%)$ и Правительством Каталонии $(46,2 \%)$, на работе $(45,5 \%)$ и, разумеется, в семье. Статистические данные также показывают, что самый низкий процент носителей каталанского языка фиксируется в Барселоне (свыше 30\%), тогда как в горных районах эта цифра резко возрастает (до 80\%).

Таким образом, хотя сопоставление цифр и процентов показывает перевес в сторону испанского, каталанский язык занимает сильные позиции в таких сферах, как делопроизводство, наука, культура, но главная из них - это образование. Именно молодое поколение, обучающееся на каталанском на всех ступенях образовательной системы, обеспечит будущее языку. Более того, в Каталонии фактически идёт процесс вытеснения испанского из школы, так как на нём преподают только такие дисциплины, как испанский язык и испанская литература. Иными словами, использование испанского в школе сведено к минимуму, а обучение в университетах ведётся преимущественно на каталанском ${ }^{5}$. Языковая политика Правительства Каталонии стремится укрепить позиции каталанского языка, пытаясь одновременно снизить значение, а если получится, то и полностью вытеснить испанский язык из разных сфер общественной жизни региона (хотя последнее открыто не декларируется).
Позиция центрального правительства Испании, по мнению испанского аналитика Висенте Баркеро, в контексте этой лингвистической ситуации остаётся пассивной. В своих публикациях этот автор возлагает всю ответственность за рост сепаратистских тенденций в Каталонии не только на Мадрид, но и на весь испанский народ: и те и другие, осуждая происходящее, не предпринимают ничего, чтобы остановить набирающий обороты процесс языкового сепаратизма, грозящий обернуться развалом страны. В то же время вряд ли можно согласиться с экспертом, который настаивает на том, что для того, чтобы переломить ситуацию, хватило бы экономических мер [Barquero 2018]. Время для этого уже упущено.

Ответ на вопрос, сумеет ли испанский язык сохраниться в Каталонии и как долго, по-прежнему зависит от того, как будут разворачиваться политические события в этом автономном сообществе Испании.

Как отмечают современные перуанские лингвисты (в том числе исследователи старейшего в Латинской Америке Университета Сан Маркос) Антонио Корнехо Полар, Карлос Гарсия Бедойа, Еспезуа Сальмон, закрепление испанского языка в Перу результат неокультурного трансъязыкового процесса [Espezúa 2017: 49-50]. Такой подход противоречит утверждению основоположника отечественной испанистики академика Г.В. Степанова о том, что в странах с большой долей автохтонного населения, говорящего на субстратных языках, испанский язык используется в основном высшими образованными слоями общества и потому практически идентичен языку-источнику, сохраняя даже архаичные пиренейские черты [Степанов 1979: 72]. Вместе с тем общество развивается, демократиза-

\footnotetext{
${ }^{4}$ Idescat. Institut d'Estadística de Catalunya, Internet Média. URL: https://www.idescat.cat/ pub/?id=eulp\&n=7229 (дата обращения: 25.11.2018).

${ }^{5}$ Cuesta $C$. Ni un colegio en Cataluña permite estudiar en castellano y menos del $1 \%$, todos privados, respeta la ley // ok diario, 20.11.2017. URL:https://okdiario.com/espana/ni-colegio-cataluna-permiteestudiar-castellano-menos-del-1-todos-privados-respeta-ley-1533466/ (дата обращения: 22.12.2019).
} 
ция втягивает в трансъязыковой процесс всё более широкие массы коренного и метисного населения, появляется так называемая «мигрирующая языковая личность» (sujeto migrante) - нестабильная и противоречивая, пытающаяся совместить в себе несхожие идентичности [Espezúa 2017: 35]. Параллельно идёт процесс «поиска корней», осмысления значимости культурноязыковых ресурсов, который то затухает, то усиливается со времён Конкисты.

Испанский язык был завезён в Перу в XVI веке группой конкистадоров, число которых было очень ограниченным 180 человек. Несмотря на малочисленность, они быстро покорили огромную империю инков. Успеху конкистадоров и католических миссионеров способствовали не только жестокие методы, но и то, что они учитывали местные условия. Первоначально катехизация проводилась на языке кечуа, который священникам пришлось выучить. На него даже были переведены священные книги. Из более чем 53 местных языков конкистадоры выбрали тот, который издревле служил своеобразным койне ${ }^{6}$, что позволило им взять в свои руки один из мощнейших объединяющих местное население инструментов [Adorno 2015: 21]. В дальнейшем отношение к автохтонным языкам менялось, но запреты на его использование не вводились.

Сейчас на близкородственных языках кечуа и аймара (quechumara или runasimi, то есть «язык народа») говорят около четырех миллионов человек из общего числа перуанцев, достигшего почти 26 миллионов. Это соотношение меняется по регионам, но всё население без исключения способно понимать и общаться на испанском языке, поскольку он является государственным $^{7}$. С мая 1975 года, согласно Декрету, принятому парламентом Республики Перу, кечуа (runasimi) также стал коофициальным языком (idioma cooficial) ${ }^{8}$. На нём выступают в парламенте, составляются административные документы, ведётся преподавание и выпускается художественная литература. При приёме на административные должности отдаётся предпочтение кандидатам, владеющим кечуа. Однако он недоступен $80 \%$ перуанцев, проживающих в городах, особенно для молодёжи. Это связано с «непрестижностью» языка их крестьянских предков, не так давно перебравшихся в город [Romero 2016: 10-22].

В то же время ситуация начинает постепенно меняться: опросы показывают, что интерес к кечуа растёт. Молодые жители Лимы, не говорящие на «деревенском» языке своих родителей, сегодня признают, что хотели бы выучить его, потому что это прибавит ценности их университетскому диплому [Espezúa 2017: 49-50]. Перуанская интеллигенция и бюрократия, понимая, что развитие страны связано с повышением её туристической привлекательности (сейчас Перу стоит на первом месте в Латинской Америке по числу приезжающих $)^{9}$, активно стремятся повысить статус автохтонного языка, фольклора и культуры в целом ${ }^{10}$. Исходя из этого, нынешнюю языковую ситуацию в Перу можно охарактеризовать как диглоссию.

Политика правительства нацелена на то, чтобы ввести в общенациональный обиход язык коренного населения, поднять его престиж и дать толчок его развитию, в первую очередь в сфере образования и культуры. Не редки случаи, когда выступле-

\footnotetext{
6 По аналогии с общеупотребимым в эллинистическом мире диалектом древнегреческого так обозначают язык междиалектного общения.

7 Wikiwand Lenguas del Perú // URL: https:// /www.wikiwand.com/es/Lenguas_del_Perú (дата обращения: 16.12.2019)

8 lbid.

9 Официальный сайт Посольства Перу в Российской Федерации. URL: http://www.embperu.ru/ tourism.html (дата обращения: 16.12.2019).

10 Большое количество сайтов и очень качественных интернет-курсов по кечуа и автохтонной культуре и истории, широко доступных в U-tub бесплатных: Quechua estudio (51 lecciones), интерактивный Diccionario quechua, HugoX ChugoX (свыше 500000 просмотров).
} 
ние в парламенте страны происходит на коофициальном «языке народа» - кечуа (runasimi) - без перевода на испанский, хотя говорящий сознаёт, что не все его поймут.

Перу - страна, не так давно пережившая очередную военную диктатуру, и ещё долго будет преодолевать последствия популистских решений. В 1970-х годах, ради повышения народной поддержки правительства, в столицу и крупные города были призваны миллионы жителей беднейших сельских районов страны. Вместе с тем эти «чолос», занявшие дома старой аристократии и буржуазии, не получили ни обещанной работы, ни социальных благ, однако обострили криминальную обстановку в агломерациях, нанесли ущерб историческим зданиям и паркам, создали районы трущоб $^{11}$. Изменили они и перуанский испанский язык, по праву считавшийся одним из самых «чистых» национальных вариантов, заметно увеличив число участников вышеупомянутого «неокультурного трансъязыкового процесса».

Академическая общественность всё более укрепляется в мысли о том, что внутри общенационального варианта испанского языка, рядом с литературным стандартом существуют страты, достойные внимания не только с точки зрения фольклористики, но и лингвокультурологии, социолингвистики и языковой политики [Espezúa 2017: 50]. Эти вариации обеспечивают единство нации: español andino (андский испанский), español motoso (деревенский испанский) или media lengua («лепет, бормотание»). Эти диалекты получают название «язык-мост», так как, инкорпорируя эле- менты кечуа в испанский, они обслуживают коммуникацию в диффузной зоне, существующей между носителями кечуа как материнского языка и носителями испанского. Всё чаще в СМИ появляются известные деятели культуры и другие высокообразованные перуанцы, которые не стесняются выступать на «андском испанском», который ещё недавно был бы подвергнут порицанию ${ }^{12}$.

Сложность социолингвистической ситуации в Перу в том, что происходит взаимовлияние разных страт друг на друга, создавая несколько диффузных зон, для которых характерна упомянутая выше «мигрирующая языковая личность». Перуанцы называют её представителей «чолос» (cholos), и это слово относится как к индейцам, так и к метисам, то есть почти ко всем перуанцам, исключая немногочисленных креолов - «чистых» потомков переселенцев из Европы. В устах последних это слово звучит презрительно (означая примерно «деревенщина», «невежа», «грубиян»). В речи самих «чолос» пейоратив исчезает и слово может звучать нейтрально и даже ласково ${ }^{13}$. Роль этих слоев, составляющих большинство населения, во внутриполитических процессах постоянно возрастает, и одновременно в стране в позитивную сторону меняется отношение к «мигрирующей языковой личности».

При всех проблемах, сложностях и скандалах современной политической, экономической и социальной жизни Перу подход администрации и академического сообшества к решению непростых языковых вопросов в стране выглядит разумным и уже даёт результаты. В условиях стабильно-

11 Мир индейцев. Радикальные реформы генерала Хуана Веласко Альварадо. Перу на пути независимого государственного развития в контексте мировой истории: 1826 год - середина 90-х годов XX века. URL: https://www.indiansworld.org/Latin/independent_peru21.html\#.Xf-cfUczaUk (дата обращения: 16.12.2019).

12 Примером таких выступлений могут служить телевизионные трансляции дебатов в парламенте экс-президента Перу Ольянта Мойсес Умала Тассо (28 июля 2011 - 28 июля 2016 г.), Председателя Левой индейской националистической партии, этнического кечуа. Моисеев А. Обзор журнала «Международная жизнь» «Кто Вы, Президент Ольянта Умала? // Перу. Поиск новых ориентиров после экономического чуда. М., 2015.

13 По экспертной оценке авторов статьи, самосознание современных перуанцев как нации, возникшей, по преимуществу, как результат метисизации, признаёт лексему «чолос» как один из конституирующих концептов, постепенно лишая её пейоративной оценочности. 
го экономического роста последние пятнадцать лет укрепляется престиж автохтонного языка, «рунасими», что, как было показано выше, привело к повышению его статуса в перуанском обществе. Тем не менее двуязычие не угрожает судьбе испанского языка в Перу, им владеет практически всё население страны.

В отличие от Каталонии и Перу, на Филиппинах испанский язык ждал печальный финал. Хотя есть основания говорить о многоязычии в стране, испанский язык в пёстрой, но довольно гармоничной ситуации диглоссии практически отсутствует. После трёхсотлетнего административного господства (с начала XVII века до начала $\mathrm{XX}$ ), а затем ещё почти векового сопротивления исчезновению, а также попыток сохранить или возродить его для общения жителей островов между собой и с мировой цивилизацией сегодня он сохранился здесь лишь в именах и фамилиях, а также географических названиях [Anderson 1983: 45; Alvarez Tardío 2009: 11-15]. Ономастика и топонимика продолжают подтверждать сведения Института Сервантеса о том, что Филиппины всё ещё относятся к ареалу распространения испанского языка ${ }^{14}$, но последние два коренных его носителя скончались в Маниле в 1980-х годах [Anderson 1983:45; Alvarez Tardío 2009: 11-15]. Даже в городе Кавите, где когда-то большинство жителей считало родным языком испанский, он фактически вышел из употребления [Anderson 1983: 45; Alvarez Tardío 2009: 11-15].

Вплоть до начала XX века испанский был языком государственной администрации, армии, литературы, на нём регистрировались акты гражданского состояния, на его базе осуществлялось школьное образование и он служил lingua franca на всех островных территориях. В основном он носил письменно-официальный характер, и социолингвистическая ситуация к началу $\mathrm{XX}$ века выглядела примерно так: для $1 \%$ населения он был единственно родным, $60 \%$ свободно владели им как вторым, третьим или иностранным [Rodríguez Ponga 2003: 49-53]. На юге страны, на полуострове Замбоанга, бытовал креольский вариант испанского, так называемый «чабакано» (chabacano), на котором говорили (и сейчас говорят) около 0,6 млн человек ${ }^{15}$. Следует к тому же отметить, что до $40 \%$ лексического фонда автохтонных языков составляют заимствования из испанского.

Испанский был языком движения за независимость, развернувшегося на Филиппинах в конце XIX века. Такие выдающиеся филиппинцы, как Хосе Рисаль, Марсело дель Пилар - вдохновители потерпевшей неудачу национально-освободительной революции 1896-1898 годов, писали свои памфлеты, статьи, романы и пьесы по-испански [Anderson 1983: 115, 142]. Даже после поражения Испании в войне 1898 года национальная интеллигенция в знак протеста против американского влияния продолжала использовать язык бывших колонизаторов на радио и телевидении вплоть до 1935 года, когда официальным языком (пока вместе с испанским) не был объявлен английский [Alvarez Tardío 2009: 14]. Переходная ситуация сохранялась вплоть до 1973 года, когда испанский язык потерял статус официального, а в 1987 г. было отменено обязательное его изучение в школах. Попытка президента страны Глории Арройо возобновить его преподавание в 2008 г. эффекта не возымела [Alvarez Tardío 2009: 14].

На первый взгляд исчезновение испанского языка на Филиппинах можно было бы объяснить тем, что Испания потеряла контроль над данной территорией в 1898 г.

\footnotetext{
14 Instituto Cervantes. El español en Filipinas. URL: https://www.cervantes.es/bibliotecas documentacion_espanol/situacion_espanol_mundo/espanol_paises/filipinas.htm (дата обращения: 22.12.2019).

15 Linguapedia. Chabacano // URL: https://linguapedia.info/languages/chavakano.html (дата обращения 22.12.2019].
} 
в результате войны с США. Вместе с тем тогда же Мадрид был вынужден отказаться и от Кубы. Тем не менее испанский язык на Острове Свободы по сей день остаётся государственным. Он не имеет конкурентов, несмотря на теснейшие связи и жесткий контроль со стороны США вплоть до победы революции в 1959 году.

Одной из причин этого медленного, но удавшегося «языкового переворота» на Филиппинах стала продуманная политика, проведённая администрацией страны при содействии американских социолингвистов и с учётом изменившейся политикоэкономической ситуации в мире. Повторив в новых обстоятельствах давний опыт испанских монахов с использованием местных лингвокультурных ресурсов, а также успехи других стран, в стране «тысячи наречий» был создан общенациональный язык, призванный постепенно заменить испанский. Он был сформирован на базе автохтонных диалектов, за основу был взят разговорный речевой узус тагальского языка жителей Манилы. Параллельно начиная с 1901 г. в страну направлялись так называемые томаситы, целью которых было обучение населения английскому языку с последующим переводом лингвистической ситуации в тагало-английскую, а затем и в англо-тагальскую диглоссию ${ }^{16}$.

Вследствие этой политики в первой половине XX века доля филиппинцев, свободно владеющих испанским языком, сократилась сначала до 10, а затем и до $6 \%$. И если к середине столетия в городах ещё слышалась испанская речь, то в сельской местности этот язык понимать перестали. Процент испаноговорящих сокращался быстро за счёт более высокой рождаемости в селе. Сокрушительный удар по нему был нанесён Второй мировой войной, когда японская оккупация, американские бомбёжки, массовая эмиграция обнищавшего населения окончательно лишили испанский язык его городской базы [3D Academy]. Была и ещё одна серьёзная причи- на, лежавшая не в политико-экономической, а в идеологической плоскости. Начиная с XVI века вся обширная печатная продукция, как религиозная, так и светская (позже и электронные СМИ), подвергалась строжайшей цензуре со стороны испанской администрации, на таможне цензурировались все ввозимые книги и журналы [Anderson 1983: 28]. Эти меры не только обеспечивали желательное идеологическое влияние, но и создавали у образованного населения осознание важности слова как инструмента воздействия. Хотя либерально-демократическая и революционно настроенная филиппинская интеллигенция XIX и начала XX века писала по-испански, этот язык (важнейший инструмент в понимании народа) был связан с колониальным режимом и политическим прошлым, с отсталой и дряхлой метрополией [Anderson 1983: 167].

Английский язык ассоциировался с более демократической политикой, с современной экономикой, с передовыми культурными тенденциями, что привело к его победе [Álvarez Tardío 2009: 11-15]. Свобода слова и печати, объявленная американской администрацией сразу по завершении войны 1898 года, запустила процесс подъёма местных наречий, и после Второй мировой войны на Филиппинах сложилась специфическая социолингвистическая ситуация, в которой выбор языка стал равносильным заявлению своей политической позиции [Álvarez Tardío 2009: 11-15].

Всё связанное с испанским языком стало выглядеть элитарным, реакционным, и демократическая интеллигенция, встав в оппозицию старой элите, пользовалась английским как оружием, принятым из рук новой державы, разрушившей трёхсотлетний колониальный гнёт. Обучение на английском языке впервые давало равные возможности сделать карьеру мужчине и женщине. Таким образом, совокупность экстралингвистических факторов, включая языковую политику, привела к полному вытеснению испан-

16 3D Academy. Очень краткая история Филиппин // URL: https://3d-universal.com/ru/blogs/ 2017/03/08очень-краткая-история-филиппин/ (дата обращения: 22.12.2019). 
ского языка с территории филиппинского государства и, следовательно, из АзиатскоТихоокеанского бассейна.

$$
* * *
$$

Рассмотрение языковых ситуаций в трёх разных регионах мира позволяет выявить как общие, так и различные черты в эволюции использования испанского языка. Общим для них является стремление населения и частично администрации к возрождению и поддержке автохтонных культур. В результате сфера распространения испанского языка в рассмотренных случаях снижается. Во всех случаях прослеживается тесная связь с политическими процессами в соответствующих странах, но протекают они по-разному.

Например, в Каталонии современный каталанский язык, кодификация которого завершена, стал символом единства народа, стремящегося добиться самостоятельности не просто на уровне достигнутой автономии, а путём оформления своей государственности. Попытки решения языкового вопроса, приведшие к открытой конфронтации на самых разных уровнях: на уровне населения, автономии, центрального правительства и на европейском уровне - оказываются не совсем удачными, поскольку власти Каталонии не хотят считаться с реальностью, а именно с изменившимся соотношением коренного населения и выходцев из других регионов. Целый ряд причин стал катализатором националистических процессов, знаменем которых выступает языковой вопрос. Тем не менее испанский сохраняет важную и даже ведущую роль во многих социальных контекстах в значительной степени в связи с миграционными процессами и интегрированностью региона с другими частями страны.

В Перу отношение к испанскому языку положительное во всех регионах, даже в тех, где преобладает коренное население. Более того, на протяжении последних десятилетий наблюдалось расширение сферы его использования при одновременном размывании прежде доминировавшего литературного стиля. Вместе с тем желание сохранить свои корни и свою языковую идентичность поднимает статус языка кечуа (runasimi). Это запустило процесс нормализации и кодификации этого древнего инструмента общения на обширной территории государства инков. Поскольку политическая воля со стороны администрации и стремление большинства народа совпадают, эти процессы протекают мягко и достаточно бесконфликтно. Это, в свою очередь, со временем может привести к изменению социолингвистической ситуации, которая выглядит сейчас гармоничной.

На Филиппинах политический процесс стал определяющим в переломе языковой ситуации. В данном случае угрозу испанскому языку представляли не только автохтонные наречия и местный национализм, но и сознательная политика более развитой державы, к которой перешёл политический контроль над архипелагом. Проигрыш Испании в войне с США привёл к утере престижа языка бывших колонизаторов и быстрому вытеснению его английским в статусе официального. Политическая воля руководства страны не смогла заставить народ забыть о связи испанского языка с колониальным прошлым этой страны. Важно отметить, что региональное окружение ещё ранее обеспечивало анклавное положение испанского языка на Филиппинах в отличие от Каталонии и Перу, соседствующих с другими испаноязычными территориями.

Рассмотренные примеры подтверждают тезис о том, что государство через изменение соотношения между языками в обществе осязаемо влияет на политические процессы в стране. Лингвисты, исследуя реальные социолингвистические ситуации как детонаторы политических кризисов и конфронтаций, предсказывают вероятное развитие событий и предостерегают о вероятных конфликтных ситуациях. Языковая политика способна как успокаивать бурю, так и раздувать социальное недовольство. Успешно или неудачно будут проходить политические процессы в той или иной полиэтнической стране, во многом зависит от степени сбалансированности языковой политики государства. 


\section{Список литературь}

Азизов У.Б. Конструктивизм в международных отношениях. СПб.: Алетейя, 2015. 160 с.

Виноградов В.А. Диглоссия / Лингвистический энциклопедический словарь / Под ред. В.Н. Ярцевой. М.: Сов. Энциклопедия, 1990. 685 с.

Гак В.Г. К типологии форм языковой политики // Вопросы языкознания.1989. № 5. С. 104-133.

Гринина E.A. Судьба малых романских языков: окситанский язык // Романские языки и культуры: от античности до современности. М.: Век информации, 2013. С. 72-76.

Гринина Е.А. Государство в государстве: Аранская долина // Древняя и новая Романия. Т. 16. Вып. 2. СПб.: Изд-во. СПбГУ, 2015. С. 336-344. URL: http://elibrary.ru/contents.asp?titleid=26756 (дата обращения: 30.08.2019].

Гринина Е.А. Окситания в Каталонии // Ибероамериканские тетради. Вып.1 (11). М.: ИМИ МГИМО МИД России, 2016. С. 96-100.

Куропятник А., Куропятник М. Постмультикультурализм и культурное разнообразие в эпоху глобализации. // Международные процессы. 2018. Т. 16. № 1 (52). Январь-март. C. 29-39. URL: http: //intertrends.ru/system/Doc/ArticlePdf/1965/QxMUnAZXZM.pdf (дата обращения: 16.12.2019).

Марусенко М.А. Языковая политика Европейского Союза: институциональный, образовательный и экономический аспекты. СПб.: Изд-во СПбУ, 2014. 288 с.

Марусенко М.А. Эволюция мировой системы языков в эпоху постмодерна: языковые последствия глобализации. М.: Изд-во ВКН, 2015а. 496 с.

Марусенко М.A. Языки и национальная идентичность: современные вызовы национальному единству и территориальной целостности. М.: Научно-политическая книга, 20156. 575 с.

Прутцков Г. Тенденция к самоопределению малой нации в Европе. Опыт Каталонии // Международные процессы. 2018. Т. 16. № 3 (54). Июль-сентябрь. С. 113-125. URL: http://intertrends.ru/system/ Doc/ArticlePdf/2033/q0d69PXn4D.pdf. (дата обращения: 16.12.2019).

Романова Г.С. Каталония в Окситании // Ибероамериканские тетради. Вып.1 (11). М.: ИМИ МГИМО МИД России, 2016. С. 90-95.

Степанов Г.В. К проблеме языкового варьирования. Испанский язык Испании и Америки. М.: Наука, 1979. $328 \mathrm{c}$.

Тишков В.А. Русский язык и русскоязычное население в странах СНГ и Балтии // Вестник Российской академии наук. 2008. Т. 78. № 5. С. 415-422.

Чернов И.В. Постконструктивизм, или Теория лингвополитического реализма в международных отношениях // Вестник СПбУ. Политология. Международные отношения. 2018. Т. 11. Вып. 1. С. 86-104. https://doi.org/ 10.21638/11701/spbu06.2018.10710. 21638/11

Abellán J. Los retos del multiculturalismo para el estado moderno / Pluralismo, tolerancia, multiculturalismo. Ediciones AKAL. Madrid, 2003. P. 13-32.

Adorno R. Boserup I. Unlocking the Doors to the World of Guaman Poma and his Nueva corónica. The Royal Library Museum Tisculanum Press, Copenhagen, 2015. 483 p.

Alvarez Tardío, B. La literatura filipina en español. // Cuentos de Juana. Narraciones malayas de las Islas Filipinas. Instituto Cervantes, Manila, 2009. 292 p. P. 11-15.

Anderson B. Imagined Communities. Reflectiones on the Origin and Spread of Nationalism // Ed. Verso, London; New York, 1983. 240 p.

Barquero V. El separatismo catalán y el paso del tiempo // La Gaceta, 23.05.2018. URL: https://gaceta. es/opinion/el-separatismo-catalan-y-el-paso-del-tiempo-20180523-0841/ (дата обращения: 25.09.2019).

Espezúa Salmón D. Las consciencias lingüísticas en la literatura peruana. // Ed. Lima, Perú, 2017. 483 p.

La Educacion bilingue desde una vision integrada e integradora / Ed. Sintesis, Universidad de Cordoba, 2018. 224 p.

Martel Ph. L'occitan. // Histoire sociale des langues de France. Press Universitaires de Rennes, 2013. P. 511-532.

Meissner F.-J. La didáctica de la intercomprensión y sus repercusiones en la enseñanza de lenguas // Synergies Chili $n^{\circ}$ 6. 2010. P. 59-70. URL: http://ressources-cla.univ-fcomte.fr/gerflint/Chili6/ franz_joseph_meissner.pdf (дата обращения: 15.10.2018)

Pujol Berché M. Política lingüística: lengua, cultura e identidad, el ejemplo de Cataluña // Amnis [Online], 2013. URL : http://journals.openedition.org/amnis/2061 (дата обращения: 16.12.2019).

Rodríguez Ponga R. Pero ¿cuántos hablan español en Filipinas? // Cuadernos hispanoamericanos, 631, enero 2003.Madrid. P. 45-58.

Romero N. Los conceptos de centro y periferia en el proyecto transmoderno de Enrique Dussel. // Tesis. Revista de Investigación. Unidad de Postgrado. Facultad de Letras y Ciencias Humanas. Universidad Nacional Mayor de San Marcos. Año X, №9, Vol. 9. Dic. 2016. P. 10-22. 
Sanchéz Carrión J.M. Bilingüismo, diglosia y contacto de lenguas / Anuario de Filología Vasca «Julio de Urquijo» // San Sebastián, 1976. P. 3-79.

Vilar P. Breve historia de Cataluña // Edicions UAB, Barcelona, 2011. 162 p.

\title{
"YOU REAP WHAT YOU SOW" LANGUAGE POLICIES AND LINGUISTIC SITUATION IN FORMER AND CLRRENT SPANISH TERRITORIES
}

\author{
ELENA GRININA \\ GALINA ROMANOVA \\ MGIMO University, Moscow, 119454, Russian Federation
}

\begin{abstract}
The article deals with governments language politics and sociolinguistic situations in the three different and distant entitites: Catalonia (Spain), Peru and Philippines. Being importes in the XVI century, the Spanish language was the only common element to the countries. However, nowadays the destiny of the language is different. The analyses indicate that there is a balanced language politics in a polyethnic state is a key to successful governance. Spanish which was imported to the former colonies forced out local Catalan, Quechua, and Tagalog from almost spheres including governance, economy, and culture. Those languages were used only in families and ordinary life situations. Nevertheless, gradually local languages reconquered their positions. For instance, in Catalonia the process was a success leading to the Spanish government concerns about the future of Spanish in the autonomous community. As for Quechua (Runasimi), the Peruvian government is positive about the re-establishment of the role of the language giving it the co-official status. Spanish and Runasimi are interinfluencing each other, as well. The Philippines is a different case given that English has replaced Spanish as an official language. The authors emphasize that language destiny is defined by linguistic politics of a state.
\end{abstract}

\section{Keywords:}

language politics; linguistic situation; multilingualism; bilingualism; diglossia; language worldview; linguistic personality; Spanish; Catalan; Quechua; Catalonia; Peru; Philippines.

\section{References}

(2018). La Educacion bilingue desde una vision integrada e integradora. Sintesis, Universidad de Cordoba. $224 \mathrm{p}$.

Abellán J. (2003). Los retos del multiculturalismo para el estado moderno. Pluralismo, tolerancia, multiculturalismo. Ediciones AKAL, Madrid. P. 13-32.

Adorno R. Boserup I. (2015). Unlocking the Doors to the World of Guaman Poma and his Nueva corónica. Ed. The Royal Library Museum Tisculanum Press, Copenhagen, 2015. 483 p.

Alvarez Tardío, B. (2009). La literatura filipina en español. In: Cuentos de Juana. Narraciones malayas de las Islas Filipinas. Ed. Instituto Cervantes, Manila. 292 p.

Anderson B. (1983). Imagined Communities. Reflectiones on the Origin and Spread of Nationalism. London; New York: Verso. 240 p.

Azizov U.B. (2015). Konstruktivizm v mezhdunarodnykh otnosheniyakh. [Constructivism in international relations]. Sankt-Peterburg: Aleteyya. $160 \mathrm{p}$.

Barquero V. (2018). El separatismo catalán y el paso del tiempo. La Gaceta. URL: https://gaceta.es/ opinion/el-separatismo-catalan-y-el-paso-del-tiempo-20180523-0841/ laccessed: 25.09.2019). 
Chernov I.V. (2018). Postkonstruktivizm, ili Teoriya lingvopoliticheskogo realizma v mezhdunarodnykh otnosheniyakh [Postconstructivism, or Theory of Linguopolitical Realism in International Relations]. Vestnik Sankt-Peterburgskogo universiteta. Politologiya. Mezhdunarodnyye otnosheniya. Vol. 11. No. 1. P. 86-104. https://doi.org/ 10.21638/11701/spbu06.2018.10710.21638/11

Espezúa Salmón D. (2017). Las consciencias lingüísticas en la literatura peruana. Ed. Lima, Perú. 483 p.

Gak V. (1989). K tipologii form yazykovoy politiki [About typology of forms of the language politics]. In: Voprosy Yazikoznanya. No. 5. P. 104-133.

Grinina E. (2013]. Sudyba malyj romanskij yazikov: oksitansky yazyk [Destinies of minor roman languages: occitan]. In: Romanskye yazyki I kultury: ot antichnosti do sovremennosty [Roman languages and cultures: from Antiquity up to Modern times]. M.: Vek informatsii. P. 72-76.

Grinina E. (2015). Gosudarstvo v gosudarstve: Aranskaya dolina [State within a state: Aran Valley]. In: Drevnyaya i novaya Romaniya [Ancient and new Romania]. Vol.16. No. 2. Sankt-Peterburg: Izdatel'stvo Sankt-Peterburgskogo universiteta. P. 336-344.

Grinina E. (2016). Oksitania v Katalonii [Occitania in Catalonia]. Journal of Ibero-American notebooks. Ed. No. 1(11). P. 96-100.

Kuropiatnik A., Kuropiatnik M. Postmul'tikul'turalizm i kul'turnoye raznoobraziye v epokhu globalizatsii [Post-multiculturalism and cultural diversity in the era of globalization.]. // In Mezhdunarodnyye protsessy. Vol 16. No 1 (52). January - March / 2018. P. 29-39 URL: http: //intertrends.ru/system/ Doc/ArticlePdf/1965/QxMUnAZXZM.pdf laccessed: 16.12.2019).

Martel Ph. (2013). L'occitan. In: Histoire sociale des langues de France. Ed. Press Universitaires de Rennes. P. $511-532$.

Marusenko M.A. (2014). Yazykovaya politika Yevropeyskogo Soyuza: institutsional'nyy, obrazovatel'nyy i ekonomicheskiy aspekty [The language policy of the European Union: institutional, educational and economic aspects.] Saint-Petersburg: Izdatel'stvo Sankt-Peterburgskogo universiteta. 288 p.

Marusenko M.A. (2015a). Evolyutsiya mirovoy sistemy yazykov v epokhu postmoderna: yazykovyye posledstviya globalizatsii [ The evolution of the global system of languages in the postmodern era: the linguistic consequences of globalization.] Moscow: Izdatel'stvo VKN. 496 p.

Marusenko M.A. (2015b). Yazyki i natsional'naya identichnost': sovremennyye vyzovy natsional'nomu yedinstvu i territorial'noy tselostnosti [Languages and national identity: modern challenges to national unity and territorial integrity]. Moscow: Nauchno-politicheskaya kniga. 575 p.

Meissner F.-J. (2010). La didáctica de la intercomprensión y sus repercusiones en la enseñanza de lenguas. Synergies Chili. No 6. P. 59-70. URL : http://ressources-cla.univ-fcomte.fr/gerflint/Chili6/ franz joseph meissner.pdf (accessed: 15.10.2018)

Prutsskov G. ( $\overline{2} 018$ ) Tendentsiya k samoopredeleniyu maloy natsii v Yevrope. Opyt Katalonii [Selfdetermination of smaller nations in Europe. The case of Catalonia]. Mezhdunarodnye processy. Vol. 16, №3 [54], p.113-125. URL: http://intertrends.ru/system/Doc/ArticlePdf/2033/q0d69PXn4D.pdf. (accessed: 16.12.2019).

Pujol Berché M. (2013). Política lingüística: lengua, cultura e identidad, el ejemplo de Cataluña. Amnis [Online]. URL : http://journals.openedition.org/amnis/2061 laccessed: 16.12.2019].

Rodríguez Ponga R. (2003) Pero ¿cuántos hablan español en Filipinas? In: Cuadernos hispanoamericanos, 631, enero 2003.Madrid. P. 45-58.

Romanova G. (2016). Katalonia v Oksitanii [Catalonia in Occitania]. Journal of Ibero-American notebooks. No. 1 (11). P. 90-95.

Romero N. (2016). Los conceptos de centro y periferia en el proyecto transmoderno de Enrique Dussel. In: Tesis. Revista de Investigación. Unidad de Postgrado. Facultad de Letras y Ciencias Humanas. Universidad Nacional Mayor de San Marcos. Año X, №9, vol.9. Dic.2016. P. 10-22.

Sanchéz Carrión J.M. (1976). Bilingüismo, diglosia y contacto de lenguas. In: Anuario de Filología Vasca "Julio de Urquijo». San Sebastián. P. 3-79.

Stepanov G. V. (1979). K probleme yazykovogo var'irovaniya. Ispanskiy yazyk Ispanii I Ameriki. [About the problem of linguistic variation. Spanish language of Spain and America]. Moscow: Nauka. 328 p.

Tishkov V.A. (2008). Russkiy yazyk i russkoyazychnoye naseleniye v stranakh SNG i Baltii [The Russian language and the Russian-speaking population in the CIS and Baltic countries]. Vestnik Rossiyskoy akademii nauk. Vol. 78. No. 5. P. 415-422.

Vilar P. (2011). Breve historia de Cataluña // Edicions UAB, Barcelona. - 162 p.

Vinogradov V. (1990). Diglossia [Diglossia]. In: Lingvistichesky entziklopedichesky slovar [Linguistic encyclopaedic dictionary]. Directed by V. Yartseva. Moscow.: Sov. Entsyclopedia. 685 p. 